University of Nebraska - Lincoln

DigitalCommons@University of Nebraska - Lincoln

\title{
Effects of Forage Quality and Cell Wall Constituents of Bermuda Grass on Biochemical Conversion to Ethanol
}

\author{
William F. Anderson \\ USDA/ARS Crop Genetics and Breeding Research Unit, bill.anderson@ars.usda.gov \\ Bruce S. Dien \\ USDA-ARS, Bruce.Dien@ars.usda.gov \\ Hans-Joachim G. Jung \\ USDA-ARS \\ Kenneth P. Vogel \\ University of Nebraska-Lincoln, kvogel1@unl.edu \\ Paul J. Weimer \\ USDA-ARS
}

Follow this and additional works at: https://digitalcommons.unl.edu/usdaarsfacpub

Anderson, William F.; Dien, Bruce S.; Jung, Hans-Joachim G.; Vogel, Kenneth P.; and Weimer, Paul J., "Effects of Forage Quality and Cell Wall Constituents of Bermuda Grass on Biochemical Conversion to Ethanol" (2010). Publications from USDA-ARS / UNL Faculty. 1958.

https://digitalcommons.unl.edu/usdaarsfacpub/1958

This Article is brought to you for free and open access by the U.S. Department of Agriculture: Agricultural Research Service, Lincoln, Nebraska at DigitalCommons@University of Nebraska - Lincoln. It has been accepted for inclusion in Publications from USDA-ARS / UNL Faculty by an authorized administrator of DigitalCommons@University of Nebraska - Lincoln. 


\title{
Effects of Forage Quality and Cell Wall Constituents of Bermuda Grass on Biochemical Conversion to Ethanol
}

\author{
William F. Anderson • Bruce S. Dien • \\ Hans-Joachim G. Jung • Kenneth P. Vogel • \\ Paul J. Weimer
}

Published online: 4 December 2009

(C) US Government 2009

\begin{abstract}
Bermuda grass is an attractive candidate as a feedstock for biofuel production because over four million hectares of Bermuda grass are already grown for forage in the Southern USA. Because both rumen digestion and biochemical conversion to ethanol depend upon enzymatic conversion of the cell wall polysaccharides into fermentable sugars, it is probable that grasses bred for increased forage quality would be more amenable for ethanol production. However, it is not known how variation in rumen digestibility and cell wall/fiber components correlates with efficiency of conversion to ethanol via fermentation. The objective of this research was to determine relationships between ethanol production evaluated by simultaneous saccharification and fermentation (SSF), 72-h in vitro ruminal dry matter digestibility (IVDMD), in vitro ruminal gas production after 24 and $96 \mathrm{~h}$, and biomass composition for 50 genetically diverse Bermuda grass accessions. The
\end{abstract}

\author{
W. F. Anderson $(\bowtie)$ \\ USDA/ARS, \\ Tifton, GA, USA \\ e-mail: bill.anderson@ars.usda.gov \\ B. S. Dien \\ USDA/ARS, \\ Peoria, IL, USA \\ H.-J. G. Jung \\ USDA/ARS, \\ St. Paul, MN, USA \\ K. P. Vogel \\ USDA/ARS, \\ Lincoln, NE, USA \\ P. J. Weimer \\ USDA/ARS \\ Madison, WI, USA
}

Bermuda grass samples were subjected to standard 72-h IVDMD and forage fiber analyses. Also, in separate labs, gas production was measured in sealed volumecalibrated vials after 24 (NNG24) and $96 \mathrm{~h}$ (NNG96) of in vitro fermentation by ruminal fluid; ethanol and pentose sugar productions were measured from a bench-top SSF procedure; cell wall constituents were determined by the Uppsala Dietary Fiber Method; and total nitrogen, carbon, and ash concentrations were determined by using the LECO combustion method. Ethanol production was moderately correlated with IVDMD $(r=0.55)$ and NNG96 $(r=0.63)$ but highly correlated with NNG24 $(r=0.93)$. Ethanol was negatively correlated with neutral detergent fiber (NDF; $r=-0.53)$ and pentose sugars $(r=-0.60)$, but not correlated with glucose content. Regression models indicated that NDF and cell wall pentose sugar concentrations had significant negative effects on ethanol production. Variation among entries for IVDMD was affected by variability of $\mathrm{NDF}$, pentose sugar concentrations, and biomass nitrogen content. Variation in Klason lignin content had only minor negative impacts on ethanol production and IVDMD. Biochemical conversion efficiency of Bermuda grass by SSF can be best estimated by NNG24 but not by IVDMD.

Keywords Bermuda grass · Biochemical conversion .

Fiber components · In vitro gas production .

Simultaneous saccharification and fermentation

$\begin{array}{ll}\text { Abbreviations } \\ \text { SSF } & \text { Simultaneous saccharification and fermentation } \\ \text { IVDMD } & \text { In vitro dry matter digestibility } \\ \text { NNG24 } & \begin{array}{l}\text { Net normalized gas production from in vitro } \\ \text { ruminal fermentation after } 24 \mathrm{~h}\end{array} \\ \text { NNG96 } & \begin{array}{l}\text { Net normalized gas production from in vitro } \\ \text { ruminal fermentation after } 96 \mathrm{~h}\end{array}\end{array}$

Abbreviations

SSF Simultaneous saccharification and fermentation

IVDMD In vitro dry matter digestibility

NNG24 Net normalized gas production from in vitro ruminal fermentation after $24 \mathrm{~h}$

ruminal fermentation after $96 \mathrm{~h}$ 


$\begin{array}{ll}\text { NDF } & \text { Neutral detergent fiber } \\ \text { ADF } & \text { Acid detergent fiber } \\ \text { ADL } & \text { Acid detergent lignin } \\ \text { UA } & \text { Uronic acids } \\ \text { KL } & \text { Klason lignin } \\ \text { PCA } & p \text {-Coumarate } \\ \text { FA } & \text { Ferulate } \\ \text { CW } & \text { Total cell wall components } \\ \text { DM } & \text { Dry matter } \\ \text { CWA } & \text { Cell wall analysis } \\ \text { DFA } & \text { Detergent fiber analysis }\end{array}$

\section{Introduction}

Most fuel ethanol used in the USA is currently produced from corn at biorefineries located in the Midwest, but further expansion of biofuel production is expected to come from lignocellulose feedstocks [33]. Bermuda grass is one potential feedstock because it is currently grown on four to five million hectares throughout the South [5] where it is used for livestock feed (grazing and hay). Growers have vast experience in the production and transport of Bermuda grass. Although the primary use of Bermuda grass has been for animal feed, improved varieties and cultural practices have increased productivity [15], making this crop an attractive source of biomass for cellulosic conversion to biofuel.

Forage grasses have been bred for high biomass yields and better forage quality (digestibility or biodegradability). Lignocellulose of grasses varies from that of other plant types (e.g., woody tissue, dicotyledonous plants) in having high concentrations of $p$-coumaric and ferulic acids [21]. These hydroxycinnamic acids occur in both ester- and ether-linked structures [34]. Lignin in grass cell walls is recalcitrant to biodegradation [3, 4].

Improved biodegradability is conferred through lower lignin content and altered lignocellulose characteristics, which might also improve its quality for use as a feedstock in biofuel production [7]. The Bermuda grass cultivars "Coastcross 1" [14] and "Tifton 85" [15] were developed for improved 96-h in vitro dry matter digestibility (IVDMD). There is evidence that the improved digestibility of these two cultivars is controlled by different mechanisms [7]. Bermuda grass, in general, compares favorably with other potential biomass feedstock grasses in its conversion potential to ethanol $[8,12]$. However, research is needed to determine how variation in ruminal digestibility and chemical composition correlate with efficiency of conversion to ethanol via fermentation. These correlations are of interest because of the extensive database that has been developed on Bermuda grass forage quality traits for various cultivars. Previously, an in vitro gas production procedure from ruminal fluids was found to be correlated with ethanol produced from bench-scale simultaneous saccharification and fermentation (SSF) [40]. A recent study by Lorenz et al. [28] found that variation in ethanol yield of corn stover was highly correlated with ruminal digestibility and lignin content. However, they did not find a correlation between glucan concentration and ethanol yield.

A plant introduction population of approximately 600 lines is preserved in a nursery in Tifton, GA, USA. The ploidy levels of these accessions range from $2 n=2 \times=18$ to $2 n=6 \times=54$. A forage Bermuda grass core collection consisting of 168 plant introductions from the entire work collection [5] was analyzed for IVDMD, neutral detergent fiber (NDF), acid detergent fiber (ADF), and acid detergent lignin (ADL) during the summer of 2005. There was significant variation among entries for IVDMD (48.3\% to $71.0 \%$ ), NDF (64.3\% to $77.3 \%)$, ADF (24.1\% to $34.5 \%$ ), and ADL (3.3\% to 9.9\%) [6]. IVDMD was negatively correlated with NDF $(r=-0.86)$ and ADF $(r=-0.58)$. There was no correlation of ADL with other traits.

It is of major interest to determine the relationships of digestibility and composition with chemical and enzymatic conversion processes and ultimately with ethanol production from plant material. The objective of this study was to determine relationships between in vitro rumen digestibility and gas production, cell wall components, total nitrogen and ash content with ethanol production, and pentose release by dilute acid pretreatment and SSF for 50 of these genetically diverse Bermuda grass accessions. The primary hypothesis was that there is a strong correlation between ethanol production and ruminal digestibility, due to the fact that many of the enzymes used by ruminal microbes to degrade forage are similar to those used in industrial conversion of lignocellulosic feedstock to ethanol. Thus, there should be a direct relationship between IVDMD and ethanol production. The dilute acid pretreatment has been the traditional pretreatment and is still used for comparisons of biomass feedstocks by the Department of Energy at the National Renewable Energy Laboratory [1]. This low-severity pretreatment was also chosen to magnify structural as opposed to compositional differences among the samples.

\section{Methods and Materials}

\section{Bermuda Grass Genotype Comparison}

Bermuda grass genotypes evaluated for this study were selected from a forage Bermuda grass core collection [5] based on high and low IVDMD, NDF, and ADF [6]. Fifty entries with the widest range in rumen digestibility and fiber were selected for the current study (Table 1). The 
Table 1 Bermuda grass entries and their ranking for high $(\mathrm{H})$, medium $(\mathrm{M})$, or low $(\mathrm{L})$ levels of IVDMD, NDF, ADF, ADL from previous screening, leaf/stem coarseness, and genetic clustering from breeder plots and the Bermuda grass core collection grown at Tifton, GA, USA in 2004

\begin{tabular}{|c|c|c|c|c|c|c|c|c|}
\hline Entry & Species & Origin & IVDMD $^{\mathrm{a}}$ & $\mathrm{NDF}^{\mathrm{a}}$ & $\mathrm{ADF}^{\mathrm{a}}$ & $\mathrm{ADL}^{\mathrm{a}}$ & $\mathrm{LC}^{\mathrm{b}}$ & Genetic cluster $^{\mathrm{c}}$ \\
\hline Coastal $^{\mathrm{d}}$ & C. dactylon & Tifton, GA & M & M & M & M & 3 & A \\
\hline Coastcross II $^{\mathrm{d}}$ & Cynodon spp. & Tifton, GA & $\mathrm{H}$ & $\mathrm{L}$ & M & M & 5 & $\mathrm{C}$ \\
\hline Tifton $85^{\mathrm{d}}$ & Cynodon spp. & Tifton, GA & $\mathrm{H}$ & M & M & M & 5 & $\mathrm{E}$ \\
\hline Tifton $68^{\mathrm{d}}$ & C. nlemfuensis & Tifton, GA & $\mathrm{H}$ & M & M & M & 5 & $\mathrm{E}$ \\
\hline PI 224148 & Cynodon spp. & South Africa & M & $\mathrm{H}$ & M & M & 2 & A \\
\hline PI 204438 & C. dactylon & Turkey & $\mathrm{H}$ & M & M & M & 5 & $\mathrm{C}$ \\
\hline PI 293616 & C. dactylon & Kenya & $\mathrm{H}$ & $\mathrm{L}$ & M & M & 5 & $\mathrm{E}$ \\
\hline PI 291588 & C. dactylon & Rhodesia & $\mathrm{L}$ & $\mathrm{H}$ & $\mathrm{H}$ & $\mathrm{H}$ & 3 & A \\
\hline Coastcross II & Cynodon spp. & Tifton, GA & $\mathrm{H}$ & $\mathrm{L}$ & M & M & 5 & $\mathrm{C}$ \\
\hline PI 292247 & C. dactylon & Philippines & $\mathrm{H}$ & $\mathrm{L}$ & $\mathrm{L}$ & $\mathrm{L}$ & 2 & $\mathrm{D}$ \\
\hline Coastcross III & Cynodon spp. & Tifton, GA & $\mathrm{H}$ & $\mathrm{H}$ & $\mathrm{H}$ & $\mathrm{H}$ & 4 & $\mathrm{~A} / \mathrm{E}$ \\
\hline PI 290879 & C. dactylon & South Africa & $\mathrm{L}$ & $\mathrm{H}$ & $\mathrm{H}$ & $\mathrm{H}$ & 1 & A \\
\hline PI 291614 & C. dactylon & South Africa & M & $\mathrm{L}$ & M & M & 3 & A \\
\hline PI 289929 & Cynodon spp. & South Africa & $\mathrm{H}$ & $\mathrm{H}$ & M & $\mathrm{H}$ & 5 & $\mathrm{E}$ \\
\hline PI 225809 & Cynodon spp. & Africa & $\mathrm{L}$ & M & M & $\mathrm{H}$ & 5 & $\mathrm{C} / \mathrm{D} / \mathrm{E}$ \\
\hline T 77-29 & Cynodon spp. & Tifton, GA & $\mathrm{H}$ & M & $\mathrm{H}$ & M & 4 & $\mathrm{E}$ \\
\hline T 77-57 & Cynodon spp. & Tifton, GA & M & $\mathrm{L}$ & $\mathrm{L}$ & M & 3 & $\mathrm{~A} / \mathrm{D} / \mathrm{E}$ \\
\hline PI 255450 & C. nlemfuensis & Kenya & $\mathrm{H}$ & $\mathrm{L}$ & M & M & 5 & $\mathrm{E}$ \\
\hline PI 291575 & C. bradleyi & Rhodesia & $\mathrm{L}$ & $\mathrm{H}$ & $\mathrm{H}$ & $\mathrm{H}$ & 2 & A \\
\hline Tifton 84 & C. nlemfuensis & Tifton, GA & $\mathrm{H}$ & M & $\mathrm{L}$ & $\mathrm{H}$ & 5 & $\mathrm{E}$ \\
\hline PI 224129 & C. dactylon & South Africa & M & $\mathrm{H}$ & $\mathrm{L}$ & $\mathrm{H}$ & 2 & $\mathrm{~A} / \mathrm{D} / \mathrm{E}$ \\
\hline PI 292509 & C. dactylon & Japan & $\mathrm{H}$ & $\mathrm{L}$ & $\mathrm{L}$ & $\mathrm{H}$ & 2 & $\mathrm{D} / \mathrm{E}$ \\
\hline PI 290884 & C. dactylon & South Africa & M & $\mathrm{H}$ & $\mathrm{H}$ & $\mathrm{H}$ & 3 & A \\
\hline PI 292253 & Cynodon spp. & Philippines & $\mathrm{H}$ & $\mathrm{L}$ & $\mathrm{L}$ & $\mathrm{H}$ & 1 & $\mathrm{~A} / \mathrm{D}$ \\
\hline PI 291193 & C. polevansii & South Africa & $\mathrm{L}$ & $\mathrm{H}$ & M & $\mathrm{H}$ & 1 & $\mathrm{~A} / \mathrm{D}$ \\
\hline PI 291958 & C. dactylon & Kenya & $\mathrm{L}$ & $\mathrm{H}$ & $\mathrm{H}$ & $\mathrm{H}$ & 2 & $\mathrm{~A} / \mathrm{D}$ \\
\hline Sandhills \#7 & Cynodon spp. & Tifton, GA & $\mathrm{H}$ & $\mathrm{L}$ & $\mathrm{L}$ & $\mathrm{H}$ & 2 & A \\
\hline PI 290661 & C. dactylon & South Africa & M & $\mathrm{H}$ & $\mathrm{H}$ & M & 2 & $\mathrm{~A} / \mathrm{D}$ \\
\hline PI 290812 & C. nlemfuensis & South Africa & M & $\mathrm{H}$ & $\mathrm{H}$ & $\mathrm{H}$ & 4 & B \\
\hline PI 203456 & C. dactylon & Turkey & $\mathrm{L}$ & $\mathrm{H}$ & $\mathrm{H}$ & $\mathrm{L}$ & 2 & A \\
\hline Т 80-23 & C. nlemfuensis & Tifton, GA & $\mathrm{H}$ & M & M & $\mathrm{L}$ & 4 & E \\
\hline PI 293606 & C. nlemfuensis & Kenya & $\mathrm{L}$ & $\mathrm{H}$ & $\mathrm{H}$ & $\mathrm{L}$ & 2 & $\mathrm{~A} / \mathrm{D}$ \\
\hline Tifton 68 & C. nlemfuensis & Tifton, GA & $\mathrm{H}$ & $\mathrm{L}$ & M & M & 5 & E \\
\hline PI 266768 & C. dactylon & Iran & $\mathrm{L}$ & M & M & M & 2 & $\mathrm{~A} / \mathrm{D}$ \\
\hline PI 301862 & Cynodon spp. & Australia & M & $\mathrm{H}$ & M & $\mathrm{L}$ & 3 & $\mathrm{~A} / \mathrm{D}$ \\
\hline PI 291189 & C. incompletus & South Africa & M & $\mathrm{H}$ & $\mathrm{H}$ & $\mathrm{L}$ & 2 & $\mathrm{~A} / \mathrm{D}$ \\
\hline PI 291744 & C. dactylon & South Africa & M & $\mathrm{H}$ & $\mathrm{H}$ & M & 2 & A \\
\hline PI 255457 & C. plectostachyus & Kenya & $\mathrm{H}$ & $\mathrm{L}$ & M & $\mathrm{L}$ & 4 & $\mathrm{~A} / \mathrm{C}$ \\
\hline PI 292610 & C. plectostachyus & Rhodesia & $\mathrm{H}$ & $\mathrm{L}$ & M & $\mathrm{L}$ & 4 & $\mathrm{~A} / \mathrm{C} / \mathrm{E}$ \\
\hline Т 78-9 & Cynodon spp. & Tifton, GA & $\mathrm{H}$ & M & M & $\mathrm{L}$ & 5 & $\mathrm{E}$ \\
\hline PI 291150 & C. dactylon & South Africa & $\mathrm{L}$ & $\mathrm{H}$ & $\mathrm{H}$ & $\mathrm{H}$ & 2 & A \\
\hline PI 291732 & C. dactylon & South Africa & M & $\mathrm{H}$ & $\mathrm{H}$ & M & 2 & \\
\hline PI 291724 & C. dactylon & South Africa & $\mathrm{L}$ & $\mathrm{H}$ & $\mathrm{H}$ & $\mathrm{L}$ & 2 & \\
\hline PI 316536 & C. dactylon & Austria & $\mathrm{H}$ & $\mathrm{L}$ & $\mathrm{L}$ & M & 4 & $\mathrm{C}$ \\
\hline PI 316416 & C. dactylon & Switzerland & $\mathrm{H}$ & $\mathrm{L}$ & M & $\mathrm{H}$ & 4 & $\mathrm{C}$ \\
\hline D-8 & C. dactylon & Miami, FL & $\mathrm{L}$ & $\mathrm{H}$ & $\mathrm{H}$ & $\mathrm{H}$ & 3 & $\mathrm{~A} / \mathrm{D} / \mathrm{E}$ \\
\hline PI 316418 & C. dactylon & Switzerland & $\mathrm{H}$ & $\mathrm{L}$ & M & M & 4 & $\mathrm{C}$ \\
\hline PI 316536 & C. dactylon & Austria & $\mathrm{H}$ & $\mathrm{L}$ & M & M & 4 & $\mathrm{C}$ \\
\hline
\end{tabular}


Table 1 (continued)

\begin{tabular}{lllllllll}
\hline Entry & Species & Origin & IVDMD $^{\mathrm{a}}$ & NDF $^{\mathrm{a}}$ & ADF $^{\mathrm{a}}$ & ADL $^{\mathrm{a}}$ & LC $^{\mathrm{b}}$ & Genetic cluster $^{\mathrm{c}}$ \\
\hline T 23-20 & C. nlemfuensis & Tifton, GA & $\mathrm{H}$ & $\mathrm{L}$ & $\mathrm{M}$ & $\mathrm{M}$ & 4 & $\mathrm{C}$ \\
T 24-17 & C. nlemfuensis & Tifton, GA & $\mathrm{H}$ & $\mathrm{L}$ & $\mathrm{M}$ & $\mathrm{M}$ & 4 & $\mathrm{C}$ \\
\hline
\end{tabular}

${ }^{\text {a }}$ IVDMD ranked high ( $\left.>62 \%\right)$, medium (55-62\%), or low $(<55 \%)$; NDF content ranked high $(>70 \%)$, medium $(68-70 \%)$, or low $(<68 \%)$; ADF content ranked high ( $>30 \%)$, medium $(28-30 \%)$, or low $(<28 \%)$; ADL content ranked high $(>6.0 \%)$, medium $(4.5-6.0 \%)$, or low $(<4.5 \%)$

${ }^{\mathrm{b}} \mathrm{LC}=$ Leaf/stem coarseness based on ratings over 3 years, Tifton, GA 2003-2005 (1, very fine; 5, very coarse)

${ }^{\mathrm{c}}$ Genetic clusters as determined by AFLPs [10]

${ }^{\mathrm{d}}$ Entries from breeder's plots

molecular genetic relationship between these entries was documented using amplified fragment-length polymorphisms (AFLP) [10]. IVDMD was ranked high $(>62 \%)$, medium $(55-62 \%)$, or low $(<55 \%)$. NDF content was ranked high $(>70 \%)$, medium $(68-70 \%)$, or low $(<68 \%)$. ADF content was ranked high $(>30 \%)$, medium $(28-30 \%)$, or low $(<28 \%)$. ADL content was ranked high $(>6.0 \%)$, medium $(4.5-6.0 \%)$, or low $(<4.5 \%)$. Bermuda grass nursery plots $\left(1 \mathrm{~m}^{2}\right)$ were mowed to approximately $10 \mathrm{~cm}$ on 19 July 2006. After 5-week regrowth (25 August 2006), three samples $(50 \mathrm{~g})$ from each plot of the core nursery at Tifton, GA, USA were hand-harvested. Five weeks is the normal recommended interval for optimal hay yield and is prior to development of inflorescences. None of the accessions were considered fully mature at 5 weeks, and this harvest interval was considered appropriate for comparing and maximizing differences. Though Bermuda grass could be harvested at intervals greater than 5 weeks, current hay practices would be continued to allow grower flexibility in marketing between hay for forage or biofuel feedstocks. Samples were bulked together, dried, and ground to $1-\mathrm{mm}$ particle size with a Wiley mill for analyses for consistent comparisons. Dry matter (DM) concentration was determined on a subsample that was not used for other analyses by heating in a forced-air oven for $24 \mathrm{~h}$ at $105^{\circ} \mathrm{C}$. Each sample was analyzed in triplicate.

\section{Digestibility (IVDMD) and Detergent Fiber Analyses}

Triplicate ground samples $(0.5 \mathrm{~g})$ from each of the 50 entries were subjected to IVDMD as described by Tilley and Terry [36] and modified by Marten and Barnes [30]. Ruminal contents were collected from two fistulated cows fed Coastal Bermuda grass hay and then digesta were squeezed through three layers of cheese cloth into an insulated cooler constantly purged with $\mathrm{CO}_{2}$. For each ruminal fluid batch, buffer solution $(1,600 \mathrm{ml})$ was added to ruminal fluid $(400 \mathrm{ml})$ and mixed with continuous $\mathrm{CO}_{2}$ purging. Samples were digested in $50 \mathrm{ml}$ of the ruminal fluid/buffer inoculum for $48 \mathrm{~h}$ after which acid pepsin was added and incubated for another $48 \mathrm{~h}$ at $39^{\circ} \mathrm{C}$. Samples were then filtered, washed, dried, and weighed as described by Tilley and Terry [36]. NDF, ADF, and ADL were determined sequentially [37] using the Ankom filter bag (Ankom Technology Corp., Fairport, NY, USA) method [38] and sulfuric acid for ADL determination. Hemicellulose was estimated as NDF minus ADF and cellulose as ADF minus ADL. Cellulose, hemicellulose, and ADL were converted to the percentage of NDF.

\section{Saccharification and Fermentation after Dilute Acid} Hydrolysis (SSF)

Each of the 50 Bermuda grass entries was pretreated with dilute acid, and the carbohydrates were converted to ethanol using an SSF scheme; each sample was evaluated in triplicate as described in Anderson et al. [9]. Two samples of midmaturity switchgrass (MPV-2) were used as internal checks [17]. Dry weights were determined after drying at $105^{\circ} \mathrm{C}$ for $24 \mathrm{~h}$. Samples $(1.5 \mathrm{~g}$, dry basis) were mixed in 25 -ml Corning bottles with $1.75 \% \mathrm{w} / \mathrm{v}$ sulfuric acid $(8.5 \mathrm{ml})$ and treated at $121^{\circ} \mathrm{C}$ for $1 \mathrm{~h}$. Bottles were then cooled to room temperature and neutralized by adding $1.2 \mathrm{ml}$ sterile $10 \% w / v \mathrm{Ca}(\mathrm{OH})_{2}$ solution; $\mathrm{Ca}(\mathrm{OH})_{2}$ was kept in suspension during additions by stirring; and $0.55 \mathrm{ml}$ of sodium citrate buffer was added $(1 \mathrm{M}, \mathrm{pH}=4.5)$. Further nutrients were supplied by adding $1.1 \mathrm{ml} 10 \times$ yeast-peptone (200 g/l peptone, $100 \mathrm{~g} / 1$ yeast extract). Enzyme loadings consisted of 5 FPU Genencor GC220 cellulase per gram biomass and 12 units Novozyme 188 cellobiose ( $\beta$ glucosidase) per gram biomass. The bottles were finally inoculated with Saccharomyces cerevisiae D5A. The inoculum was prepared by transferring the yeast from a glycerol culture stored at $-80^{\circ} \mathrm{C}$ to a YPD plate $(10 \mathrm{~g} / \mathrm{l}$ yeast extract, $20 \mathrm{~g} / 1$ peptone, $20 \mathrm{~g} / 1$ glucose, and $20 \mathrm{~g} / \mathrm{l}$ agar to solidify), incubating it at $30^{\circ} \mathrm{C}$ overnight. A single colony was used to inoculate $10 \mathrm{ml}$ YPD, which was mixed at $200 \mathrm{rpm}$ and incubated at $35^{\circ} \mathrm{C}$ for $18 \mathrm{~h}$. This culture was in turn used to inoculate a $25 \mathrm{ml}$ YPD broth supplemented with 
$50 \mathrm{~g} / 1$ glucose, which was cultured at $35^{\circ} \mathrm{C}$ and $200 \mathrm{rpm}$ for an additional $18 \mathrm{~h}$ prior to being concentrated by centrifugation and resuspended to an optical density (OD) $\mathrm{A}_{600}=50$ in $1 \times$ diluent $(8.5 \mathrm{~g} \mathrm{NaCl}, 0.3 \mathrm{~g}$ anhydrous $\mathrm{KH}_{2} \mathrm{PO}_{4}, 0.6 \mathrm{~g}$ anhydrous $\mathrm{Na}_{2} \mathrm{HPO}_{4}, 0.4 \mathrm{~g}$ peptone per liter). The yeast was added in the fermentation culture to a final optical density $(600 \mathrm{~nm}, \mathrm{OD})$ of 0.5 , approximately $0.11 \mathrm{ml}$ per bottle. Bottles were incubated at $35^{\circ} \mathrm{C}$ and mixed at $150 \mathrm{rpm}$. Bottles were fitted with septum-lined caps and vented with inserted needles for $\mathrm{CO}_{2}$ exhaust. After $72 \mathrm{~h}$, fermentations were analyzed for sugars, ethanol, and acids using a SpectraSYSTEM liquid chromatography system (Thermo Finnigan, San Jose, CA, USA) equipped with an organic acids column (Aminex HPX-87H Column, $300 \times 7.8 \mathrm{~mm}$, Bio-Rad Laboratories, Inc, Hercules, CA, USA) and a refractive index detector (RI-150, Thermo Finnigan). All sugar release results were reported on a hydrated basis. Theoretical total ethanol yields were calculated as the sum of observed ethanol production from SSF and assumed 100\% conversion of released pentose sugars (pentose sugar $\times 0.51$ ).

\section{Net Normalized Gas Production from In Vitro Ruminal Fermentation (NNG)}

The 50 Bermuda grass samples were analyzed for fermentability using an in vitro ruminal gas production assay as described by Weimer et al. [40] The ruminal inoculum was obtained from two lactating, ruminally fistulated Holstein cows that received a once-daily total mixed ration (TMR) of $30 \%$ corn grain, $30 \%$ alfalfa silage, $30 \%$ corn silage, $10 \%$ soybean meal, plus supplemental vitamins and minerals. In addition, each cow was given approximately $1 \mathrm{~kg}$ of mixed grass hay (containing both $\mathrm{C} 3$ and $\mathrm{C} 4$ species) prior to daily TMR feeding. Details for preparation of the composited ruminal inoculum have been described previously [40]. Fermentations were conducted in sealed volume-calibrated vials (nominal volume $60 \mathrm{ml}$ ), as described previously, with gas production at 24 and $96 \mathrm{~h}$ used as a measure of biodegradability of substrate [40]. Fermentations were conducted over the course of three separate runs, each with a single replicate of each sample. Net gas production values at 24 and $96 \mathrm{~h}$, calculated from headspace gas pressure measured with a digital pressure gauge, were calculated on a per gram dry substrate basis after subtraction of the average gas production from six blank vials. To correct for slight differences in the characteristics of the ruminal inocula across runs, the gas production values were adjusted to net normalized gas production (NNG) across individual runs to yield values for net normalized gas production at $24 \mathrm{~h}(\mathrm{NNG} 24)$ and at $96 \mathrm{~h}$ (NNG96); normalizations were conducted using a ratio of net gas production in triplicate standard samples (Coastal Bermuda grass) within a particular run, divided by the mean net gas production in standard samples across all runs. For the three runs, these ratios were $0.974,0.962$, and 1.071 at $24 \mathrm{~h}$ and $0.975,1.034$, and 0.993 at $96 \mathrm{~h}$.

Total Carbon, Nitrogen, and Ash

Total nitrogen $(\mathrm{N})$ and carbon (C) concentrations were determined for duplicate $0.5 \mathrm{~g}$ samples of the 50 entries at the University of Nebraska Agronomy and Horticultural Department's analytical laboratory using the LECO combustion method (Model FP 428 and FP 2000, LECO Corp., St. Joseph, MI, USA) $[13,39]$. Total mineral or ash content (ASH) was measured as residual sample weight after combustion at $450^{\circ} \mathrm{C}$ for $16 \mathrm{~h}$ in a muffle furnace.

\section{Cell Wall Analysis}

Bermuda grass cell wall constituents were determined by the Uppsala Dietary Fiber Method [35]. The ground Bermuda grass samples were treated with heat-stable $\alpha$ amylase at $90^{\circ} \mathrm{C}$ for $60 \mathrm{~min}$ and then with amyloglucosidase at $60^{\circ} \mathrm{C}$ for $3 \mathrm{~h}$ in $0.1 \mathrm{M}$ acetate buffer, $\mathrm{pH} 5$, to hydrolyze starch. Soluble sugars were removed by adding sufficient $95 \% \mathrm{vol} / \mathrm{vol}$ ethanol to the buffer solution to reach an alcohol concentration of $80 \%$, and the supernatant was removed after centrifugation for $15 \mathrm{~min}$ at $1,660 \times \mathrm{g}$. The crude cell wall residue that remained was subjected to a two-stage sulfuric acid hydrolysis. A solution of $12 \mathrm{M} \mathrm{H}_{2} \mathrm{SO}_{4}$ was used to solubilize the cell wall polysaccharides at $30^{\circ} \mathrm{C}$ for $1 \mathrm{~h}$, after which the reaction mixture was diluted with water to a concentration of $0.3 \mathrm{M}$ $\mathrm{H}_{2} \mathrm{SO}_{4}$ and hydrolyzed at $121^{\circ} \mathrm{C}$ in an autoclave for $60 \mathrm{~min}$. After dilution of the first stage of the acid hydrolysis procedure, an aliquot was collected and analyzed for total UA by a colorimetric method, using glucuronic acid as the reference standard [2]. Each of the Bermuda grass samples was then filtered through a coarse Gooch crucible fitted with a glass fiber filter mat to recover the acid-insoluble residue and supernatant. The neutral sugars in the supernatant resulting from the acid hydrolysis were analyzed as their alditol acetate derivatives by GC-flame ionization detector using an SP-2380 capillary column $(30 \mathrm{~m} \times 0.25 \mathrm{~mm} \times 0.2 \mu \mathrm{m}$ film thickness, Supelco, Inc., Bellefonte, PA, USA) [35]. Lignin concentration was determined by combustion of the acidinsoluble residue in a muffle furnace overnight at $450^{\circ} \mathrm{C}$. Klason lignin (KL) was calculated as the difference in weight between the acid-insoluble residue and the ash remaining after combustion.

The hydroxycinnamate fractions of the Bermuda grass cell walls were also determined. After preparation of a 
crude cell wall residue as described above, samples were extracted with $\mathrm{O}_{2}$-free $2 \mathrm{M} \mathrm{NaOH}$ at $39^{\circ} \mathrm{C}$ for $24 \mathrm{~h}$ to cleave ester-linked ferulates and $p$-coumarates from the cell wall as described by Jung and Shalita-Jones [25]. A second set of Bermuda grass cell wall residues were treated with $\mathrm{O}_{2}$-free $4 \mathrm{M} \mathrm{NaOH}$ at $170^{\circ} \mathrm{C}$ for $2 \mathrm{~h}$ in a fluidized-bed sand bath to hydrolyze both ester- and ether-linked ferulates [23]. The supernatants from each set of alkali extractions were acidified to $\mathrm{pH} 1.5$ to 1.6 using concentrated phosphoric acid. The supernatants were then centrifuged and filtered through a $0.45-\mu \mathrm{m}$ filter, and $\mathrm{C}_{18}$ solid-phase extraction columns were used to remove free ferulic and $p$-coumaric acid residues from the acidified extracts [25]. Methanol $(50 \% v / v)$ was used to elute the hydroxycinnamic acids from the extraction columns, and concentrations of ferulic and $p$-coumaric acids in the methanol solutions were measured by HPLC using a Spherisorb-ODS2, $\mathrm{C}_{18}, 5-\mu \mathrm{m}$ column (Waters Corp., Milford, MA, USA). The elution solvent $(97.7 \%$ water $/ 0.3 \%$ glacial acetic acid $/ 2 \%$ butanol, $v / v / v)$ was pumped at $1.8 \mathrm{ml} / \mathrm{min}$, at a column temperature of $50^{\circ} \mathrm{C}$, and hydroxycinnamic acids were monitored at $320 \mathrm{~nm}$ [20, 25]. Ester-linked hydroxycinnamate (EST) concentrations were derived from the $2 \mathrm{M} \mathrm{NaOH}$ extracts while the etherified ferulates (ETH) were calculated as the difference in ferulate concentrations between the 2 and $4 \mathrm{M}$ $\mathrm{NaOH}$ extractions [23].

All cell wall sugar data were converted to an anhydro basis to reflect their presence in polysaccharides. Cell wall pentose sugars were calculated as the sum of arabinose and xylose and hexose sugars as the sum of glucose, galactose, and mannose. Whereas cell wall polysaccharides were expressed as a proportion of total DM, Klason lignin (\%KL) and ester- (\%EST) and ether-linked $(\% \mathrm{ETH})$ ferulates were expressed as a percentage of total cell wall. To estimate the percent of pentose sugars released from the SSF procedure, pentose sugar released by SSF was converted to an anhydro basis and divided by the pentose sugars determined by cell wall analyses.

Data analysis was conducted using SAS software (SAS Institute Inc., Cary, NC, USA). Analyses included PROC GLM for comparisons among plant material and PROC CORR for correlations among traits. All traits were standardized for non-bias regression by subtracting entry means for each trait from the overall mean of that trait and dividing by two times the standard deviation of means [18]. Simple regressions were performed between estimates of IVDMD, ethanol production, NNG24, and NNG96. Multiple regressions were performed for IVDMD, ethanol, NNG24, and NNG96 using PROC STEPWISE options forward, backward, and max $R^{2}$ on models with variables from DFA, $\mathrm{C}$ and $\mathrm{N}$ composition, and the CWA. Correlation coefficients were considered high with $r \geq 0.75$, moderate with $r=0.50$ to 0.75 and low with $r<0.50$.

\section{Results}

The 50 Bermuda grass germplasm lines selected represent a range of IVDMD, NDF, and ADF from the Bermuda grass core collection [5]. Among these germplasm lines, a wide range was observed for ethanol yields, forage, and compositional traits (Table 2). Bermuda grass samples contained essentially no rhamnose (mean of $0.98 \mathrm{mg} / \mathrm{g}$ ) or fucose (mean of $0.02 \mathrm{mg} / \mathrm{g}$ ), while uronic acid (19-23 mg/g), arabinose $(32-42 \mathrm{mg} / \mathrm{g})$, mannose $(8-10 \mathrm{mg} / \mathrm{g})$, galactose $(12-17 \mathrm{mg} / \mathrm{g})$, and total percentage of carbon $(43.8-45.31 \%)$ had low variability among entries and are not reported in Tables 2 and 3.

\section{Pearson Correlation Coefficients}

Ethanol production had a moderate positive correlation with IVDMD $(r=0.55)$ and a negative correlation with NDF $(r=-0.53$; Table 3$)$. However, the pentoses released by the SSF procedure had a high negative correlation with

Table 2 Mean and range of values among 50 Bermuda grass genotypes for IVDMD; detergent fiber analysis, SSF conversion (ethanol, pentoses released), net normalized gas production from in vitro ruminal digestion (NNG24, NNG96), nitrogen and ash content, and CWA (Klason lignin, xylose, glucose, ester-linked $p$-coumaric acid, ester-linked ferulic acid, ether-linked ferulic acid, and cell wall)

\begin{tabular}{|c|c|c|}
\hline Trait & Mean & Range \\
\hline $\begin{array}{l}\text { In vitro dry matter digestibility } \\
(\mathrm{mg} / \mathrm{g} \mathrm{DM})\end{array}$ & 56.9 & $47.6-69.8$ \\
\hline $\begin{array}{l}\text { Neutral detergent fiber } \\
(\mathrm{mg} / \mathrm{g} \mathrm{DM})\end{array}$ & 73.0 & $65.7-80.4$ \\
\hline Acid detergent fiber (mg/g DM) & 31.6 & $24.4-35.2$ \\
\hline Acid detergent lignin (mg/g DM) & 7.6 & $3.3-8.8$ \\
\hline Ethanol from SSF (mg/g DM) & 139.9 & $105.3-167.3$ \\
\hline $\begin{array}{l}\text { Pentoses released from SSF } \\
(\mathrm{mg} / \mathrm{g} \mathrm{DM})\end{array}$ & 176.6 & $141.3-222.0$ \\
\hline $\begin{array}{l}\text { Gas from in vitro } \\
\text { (NNG24; } \mathrm{ml} / \mathrm{g} \mathrm{DM})\end{array}$ & 81.5 & $70.8-90.4$ \\
\hline $\begin{array}{l}\text { Gas from in vitro } \\
\text { (NNG96; ml/g DM) }\end{array}$ & 248.5 & $206.3-287.9$ \\
\hline Nitrogen content (mg/g DM) & 1.8 & $1.3-2.5$ \\
\hline Ash content (mg/g DM) & 6.9 & $5.3-8.9$ \\
\hline $\begin{array}{l}\text { Klason lignin from CWA } \\
(\mathrm{mg} / \mathrm{g} \mathrm{DM})\end{array}$ & 94.0 & $69.0-117.0$ \\
\hline Xylose from CWA (mg/g DM) & 207.0 & $180.0-236.0$ \\
\hline Glucose from CWA (mg/g DM) & 266.0 & $199.0-293.0$ \\
\hline $\begin{array}{l}\text { Ester-linked } p \text {-coumaric acid } \\
\text { from CWA }(\mathrm{mg} / \mathrm{g} \mathrm{DM})\end{array}$ & 6.0 & $4.5-7.8$ \\
\hline $\begin{array}{l}\text { Ester-linked ferulic acid from } \\
\text { CWA (mg/g DM) }\end{array}$ & 5.0 & $3.2-6.6$ \\
\hline $\begin{array}{l}\text { Ether-linked ferulic acid form } \\
\text { CWA (mg/g DM) }\end{array}$ & 1.0 & $0-2.6$ \\
\hline $\begin{array}{l}\text { Total cell wall components form } \\
\text { CWA (mg/g DM) }\end{array}$ & 623.0 & $545.0-693.0$ \\
\hline
\end{tabular}


Table 3 Pearson correlation coefficients for in vitro dry matter digestibility, DFA, ash, and CWA with ethanol production, pentose release by simultaneous saccharification and fermentation, theoretical ethanol yield, and in vitro gas production (NNG24, NNG96)

\begin{tabular}{|c|c|c|c|c|c|}
\hline & Ethanol $^{\mathrm{a}}$ & Pentose release & Theoretical ethanol yield ${ }^{\mathrm{b}}$ & NNG24 & NNG96 \\
\hline IVDMD & $0.55^{* *}$ & $-0.81 * *$ & NS & $0.38 * *$ & $0.73 *$ \\
\hline NDF (DFA) & $-0.53 * *$ & $0.76^{* *}$ & NS & NS & $-0.36^{*}$ \\
\hline Hemicellulose (DFA) & $-0.34 *$ & NS & NS & $-0.48 * *$ & $-0.62 * *$ \\
\hline Cellulose (DFA) & $0.31 * *$ & NS & NS & $0.44 * *$ & $0.59^{* *}$ \\
\hline $\mathrm{ADL}(\mathrm{DFA})$ & NS & NS & NS & NS & $-0.39 * *$ \\
\hline Total Ash & NS & $-0.55^{* *}$ & $-0.40 * *$ & NS & NS \\
\hline \% Klason lignin (CWA) & $-0.45^{* *}$ & $0.30^{*}$ & NS & $-0.52 * *$ & $-0.70 * *$ \\
\hline Pentose sugars (CWA) & $-0.60 * *$ & $0.89^{* *}$ & NS & $-0.35^{* *}$ & $-0.46^{* *}$ \\
\hline Glucose (CWA) & NS & NS & $0.31 *$ & $0.38 * *$ & $0.37 * *$ \\
\hline$\% p$-coumarate esters (CWA) & $-0.42 *$ & $0.59 * *$ & NS & NS & NS \\
\hline$\%$ Ferulate esters (CWA) & NS & NS & NS & NS & $0.68 * *$ \\
\hline$\%$ Ferulate ethers (CWA) & NS & $0.32 *$ & NS & NS & $-0.42 *$ \\
\hline Total cell wall & $-0.44 * *$ & $0.78^{* *}$ & NS & NS & NS \\
\hline
\end{tabular}

NS not significant

${ }^{*} p=0.05 ; * * p=0.01$ (significant at these probability levels)

${ }^{a}$ Ethanol measured from SSF

${ }^{\mathrm{b}}$ Theoretical ethanol production $=($ measured ethanol production from SSF $)+($ pentose sugars released from $\mathrm{SSF} \times 0.51)$

IVDMD $(r=-0.81)$ and a positive correlation with NDF $(r=0.76$; Table 3$)$. Ethanol production yielded a higher positive correlation coefficient with NNG24 $(r=0.93$; Fig. 1) than with NNG96 ( $r=0.63$; Fig. 2). Alternatively, NNG96 was a better predictor of IVDMD $(r=0.73)$ than was NNG24 $(r=0.38$; Table 3). NNG24 $(r=-0.35)$ and NNG96 $(r=-0.46)$ had significant but low negative correlations with pentose sugar released from SSF. ADL,

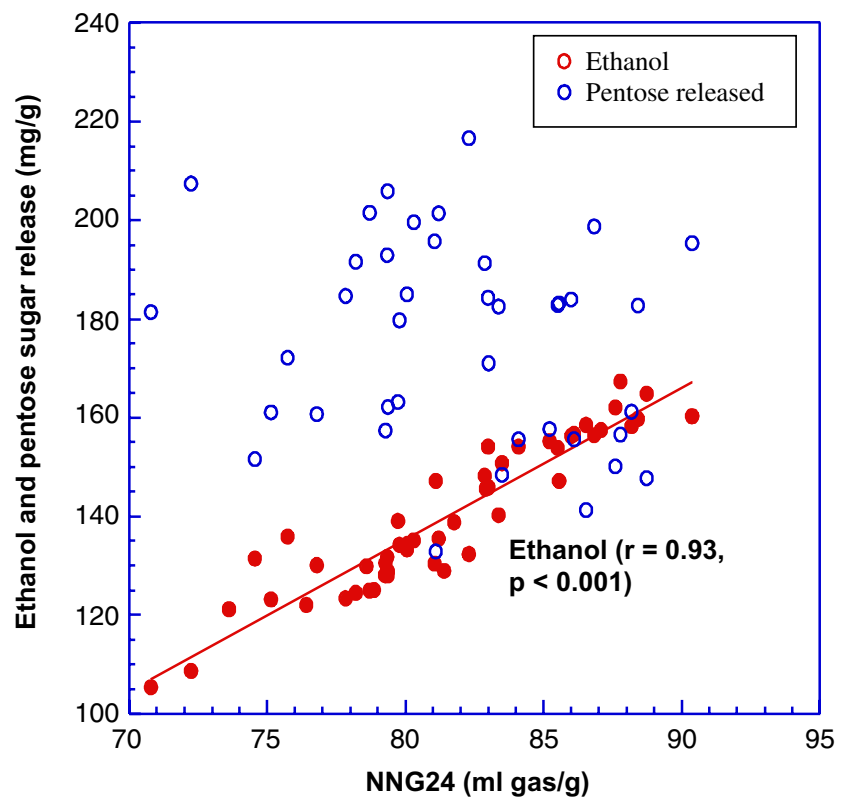

Fig. 1 Biplot of ethanol or pentose sugar released by net normalized gas production at $24 \mathrm{~h}$ (NNG24) glucose from cell wall, and the hydroxycinnamates were not significantly correlated with ethanol production. There were only two traits (ash and glucose) that showed significant correlations with theoretical ethanol yield (Table 3).

As expected, pentoses released by SSF had a high positive correlation with the percentage of pentose sugars in the cell wall as determined by the CWA ( $r=0.89$; Table 3$)$. Individually, entries with pentose levels from SSF over

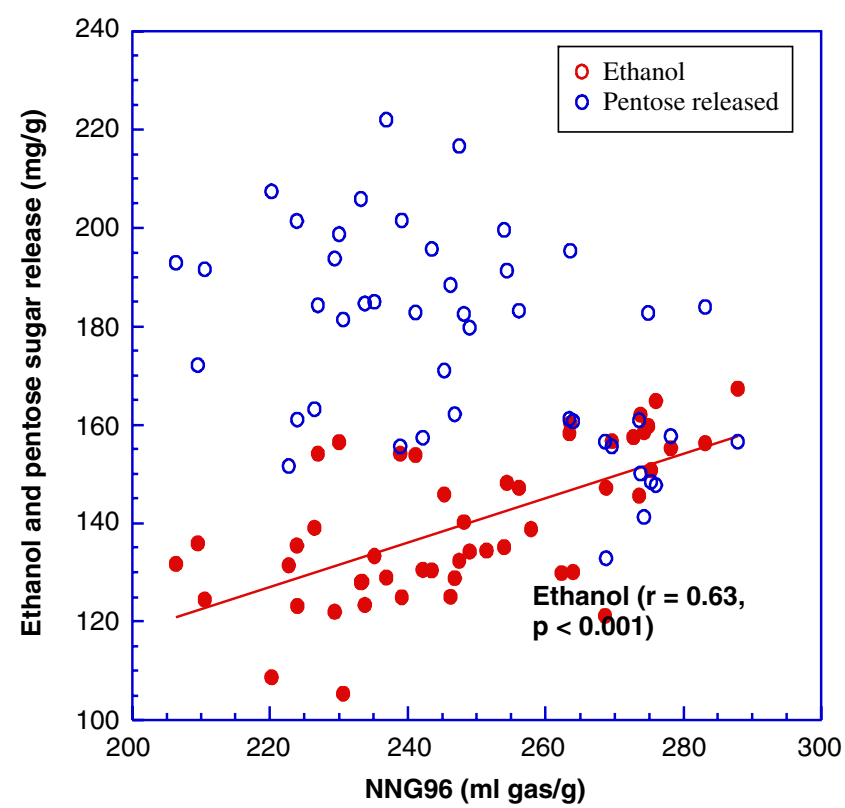

Fig. 2 Biplot of ethanol or pentose sugar released by net normalized gas production at $96 \mathrm{~h}$ (NNG96) 
$200 \mathrm{mg} / \mathrm{g}$ had high NDF and xylose levels from the CWA procedure. Although NDF is comprised of hemicellulose, cellulose, and lignin, it appears that, within these diverse Bermuda grass accessions, hemicellulose (NDF minus ADF) had the greatest influence on NDF and in turn on reduction of IVDMD and ethanol production from glucanconverting yeasts. Klason lignin had moderate negative correlations with NNG24 $(r=-0.52)$, NNG96 $(r=-0.70)$, and ethanol production $(r=-0.45)$. Interestingly, pentose sugars in the cell wall had a negative correlation with ethanol production $(r=-0.60)$ whereas glucose was not significantly correlated with ethanol yield (Table 3 ).

\section{Multiple-Regression Analysis}

NDF concentration was the greatest individual contributor to variation among entries for ethanol when all dry matter components were included in the multiple-regression model

Table 4 Best forward and backward stepwise multiple-regression models for ethanol production (SSF) for models with all variables, ash and detergent fiber analysis (DFA), or ash and cell wall analysis (CWA)

\begin{tabular}{|c|c|c|c|}
\hline Variable & Parameter est. & $F$ value & $p>F^{\mathrm{a}}$ \\
\hline \multicolumn{4}{|c|}{ Ethanol production $(S S F)$ - all parameters (full model $\left.R^{2}=0.85\right)$} \\
\hline \multicolumn{4}{|c|}{ Forward selection $\left(R^{2}=0.84\right)$} \\
\hline NDF (DFA) & -0.92 & 20.23 & $<0.001$ \\
\hline Total cell wall (CWA) & 0.39 & 4.09 & 0.060 \\
\hline Glucose (CWA) & 0.95 & 6.86 & 0.019 \\
\hline \multicolumn{4}{|c|}{ Backward selection $\left(R^{2}=0.76\right)$} \\
\hline NDF (DFA) & -0.57 & 32.41 & $<0.001$ \\
\hline Glucose (CWA) & 0.64 & 32.22 & $<0.001$ \\
\hline \multicolumn{4}{|c|}{ Ethanol production (DFA components + ash; full model $\left.R^{2}=0.51\right)$} \\
\hline \multicolumn{4}{|c|}{ Forward selection $\left(R^{2}=0.50\right)$} \\
\hline NDF & -0.82 & 37.14 & $<0.001$ \\
\hline Cellulose & 0.23 & 4.63 & 0.037 \\
\hline Ash & -0.46 & 11.10 & 0.002 \\
\hline \multicolumn{4}{|c|}{ Backward selection $\left(R^{2}=0.50\right)$} \\
\hline NDF & -0.80 & 34.58 & $<0.001$ \\
\hline Hemicellulose & -0.23 & 4.45 & 0.041 \\
\hline Ash & -0.44 & 9.74 & 0.003 \\
\hline \multirow{2}{*}{\multicolumn{4}{|c|}{$\begin{array}{l}\text { Ethanol production }\left(C W A \text { components }+ \text { ash; full model; } R^{2}=0.70\right) \\
\text { Forward selection }\left(R^{2}=0.70\right)\end{array}$}} \\
\hline & & & \\
\hline \% Klason lignin & -1.19 & 6.73 & 0.017 \\
\hline Pentose sugars & -1.27 & 15.55 & $<0.001$ \\
\hline Glucose & 1.41 & 5.42 & 0.031 \\
\hline \multicolumn{4}{|c|}{ Backward selection $\left(R^{2}=0.65\right)$} \\
\hline$\%$ Klason lignin & -1.22 & 7.18 & 0.014 \\
\hline Pentose sugars & -1.14 & 14.86 & 0.001 \\
\hline Total cell wall & -1.26 & 4.60 & 0.044 \\
\hline
\end{tabular}

${ }^{\text {a }}$ Only parameters with probability of $p<0.1$ are included in the model
(Table 4), and this was confirmed when regressing only DFA and ash components on ethanol production. Backward selection eliminated all variables except NDF and hexose sugars. Pentose sugars, Klason lignin, and total cell wall were highly significant factors negatively influencing ethanol production in the regression analysis including only CWA and ash components. Ash was a significant factor in the DFAbased regression, whereas it was not significant in the CWA regression. This is not surprising because NDF and ADF as measured included ash whereas all the CWA components were ash free. Because ash cannot be fermented, it dilutes fermentable hexose concentration and reduces the potential ethanol yield. The CWA components (pentose sugars, Klason lignin) are comparable to the negative effects on ethanol production by NDF and estimated hemicellulose of the DFA model (Table 4). Over $95 \%$ of the variation in pentose release via SSF was accounted for by the full regression model (Table 5). In this case, cell wall components measured by CWA explained greater amounts of variation $\left(R^{2}=0.86\right)$ than DFA $\left(R^{2}=0.65\right)$. Total cell wall, pentose sugar from CWA, and nitrogen content were highly significant parameters in both forward and backward selection in the full model.

The theoretical ethanol production from combining experimentally measured ethanol production plus ethanol expected from complete conversion of pentoses to ethanol was most positively correlated with NNG24 $(r=0.84)$ where ethanol production contributed the majority of the variation $(r=0.75)$. The full component multiple-regression model, with all variables included, did not explain the variation in the theoretical ethanol production $\left(R^{2}=0.27\right)$ and was not correlated with the individual cell wall components (Table 3 ). In this case, the components that negatively contributed to hexose release and subsequent conversion to ethanol were offset by the positive influence on release of pentose sugars.

The regression of all cell wall components on IVDMD resulted in an $R^{2}$ of 0.94 (Table 6). Percentages of NDF, hemicellulose, cellulose, and ADL showed negative regression coefficients for IVDMD. Also, nitrogen content of the dry matter had a highly significant positive effect on IVDMD but not on ethanol production.

\section{Discussion}

In a previous study, ethanol yields from midmaturity Bermuda grass were superior to those from immature napier grass and giant reed [9]. Stem material from the tall napier grass and giant reed was more recalcitrant than were those from their leaves. However, stems and leaves of Tifton 85 Bermuda grass produced equal amounts of ethanol. Subsequently, leaves and stems were combined for this study.

The NNG24 for Bermuda grass in this study was lower than was found in previous studies for eastern gama grass, 
Table 5 Best forward and backward stepwise multiple-regression models for pentose release (SSF) for models with all variables, ash and DFA, or ash and CWA

\begin{tabular}{|c|c|c|c|}
\hline Variable & Parameter est. & $F$ value & $p>F^{\mathrm{a}}$ \\
\hline \multicolumn{4}{|c|}{ Pentose release ( $S S F)$ - all parameters (full model $\left.R^{2}=0.96\right)$} \\
\hline \multicolumn{4}{|c|}{ Forward selection $\left(R^{2}=0.95\right)$} \\
\hline Total nitrogen & -0.35 & 27.78 & $<0.001$ \\
\hline Pentose sugars (CWA) & 0.34 & 30.02 & $<0.001$ \\
\hline Total cell wall (CWA) & 0.41 & 16.54 & $<0.001$ \\
\hline \multicolumn{4}{|c|}{ Backward selection $\left(R^{2}=0.93\right)$} \\
\hline$\%$ Cellulose (DFA) & 0.27 & 4.56 & 0.047 \\
\hline Total carbon & 0.17 & 5.48 & 0.031 \\
\hline Total nitrogen & -0.38 & 31.94 & $<0.001$ \\
\hline$\%$ Klason lignin (CWA) & 0.34 & 8.27 & 0.010 \\
\hline Pentose sugars (CWA) & 0.37 & 42.40 & $<0.001$ \\
\hline Total cell wall (CWA) & 0.32 & 11.93 & 0.003 \\
\hline \multicolumn{4}{|c|}{ Pentose release (DFA components + ash; full model $\left.R^{2}=0.65\right)$} \\
\hline \multicolumn{4}{|c|}{ Forward selection $\left(R^{2}=0.64\right)$} \\
\hline NDF & 0.62 & 29.72 & $<0.001$ \\
\hline Hemicellulose & 0.25 & 7.06 & 0.011 \\
\hline Ash & -0.22 & 3.40 & 0.072 \\
\hline \multicolumn{4}{|c|}{ Backward selection $\left(R^{2}=0.64\right)$} \\
\hline $\mathrm{NDF}$ & 0.62 & 29.72 & $<0.001$ \\
\hline Hemicellulose & 0.25 & 7.06 & 0.011 \\
\hline Ash & -0.22 & 3.40 & 0.072 \\
\hline \multicolumn{4}{|c|}{ Pentose release $\left(C W A+a s h ; R^{2}=0.86\right)$} \\
\hline \multicolumn{4}{|c|}{ Forward selection $\left(R^{2}=0.86\right)$} \\
\hline Pentose sugars & 0.42 & 36.97 & $<0.001$ \\
\hline$\%$ Ester-linked phenolics & -0.23 & 6.11 & 0.042 \\
\hline Total cell wall & 0.46 & 22.17 & $<0.001$ \\
\hline Ash & -0.30 & 9.78 & 0.005 \\
\hline \multicolumn{4}{|c|}{ Backward selection $\left(R^{2}=0.86\right)$} \\
\hline Pentose sugars & 0.42 & 36.97 & $<0.001$ \\
\hline$\%$ Ester-linked phenolics & -0.23 & 6.11 & 0.022 \\
\hline Total cell wall & 0.46 & 22.17 & $<0.001$ \\
\hline Ash & -0.30 & 9.78 & 0.005 \\
\hline
\end{tabular}

${ }^{\text {a }}$ Only parameters with probability of $p<0.1$ were included in the model

big bluestem, sand bluestem, and switchgrass [40, 41]. Though NNG24 was a better predictor of final ethanol production among Bermuda grass entries in our study, the overall higher NNG96 for Bermuda grass versus the levels of other $\mathrm{C} 4$ grasses in previous studies may be a better indicator for conversion at the biorefinery as it represents a more complete extent of fermentation.

\section{Digestibility Versus Ethanol Production}

Cellulases and related enzymes are used in converting cellulosic biomass into fuel ethanol. Microbes within the rumen use similar enzymes to digest biomass, the extent of which is measured using the IVDMD method. The very high positive correlation $(r=0.93)$ between SSF ethanol yields and $24-\mathrm{h}$ in vitro gas production (NNG24) is in accord with the reported use of the latter method as a strong predictor of ethanol production by SSF [40]. In that report, a strong correlation was observed between SSF ethanol and in vitro gas production from ground, but chemically untreated, eastern gama grass and big bluestem. Our observation of a strong correlation between NNG24 from untreated Bermuda grass samples and SSF ethanol yield from samples pretreated by dilute acid hydrolysis further extends the utility of the net normalized in vitro ruminal gas production system as a rapid screening method for ethanol conversion potential. The strong correlation further suggests that conversion of available sugars by the cellulases of SSF after $72 \mathrm{~h}$ was similar to the conversion rates of sugars by ruminal microbes after $24 \mathrm{~h}$. This may be attributed to some extent to the relative amount of hexoses available for fermentation. However, the hexose sugar composition of the cell wall measured by CWA, which is predominately glucose, did not correlate with ethanol production. This could be explained by the fact that the SSF assay directly measures ethanol yield from hexoses liberated from total biomass under low-severity pretreatment conditions minus the effects of enzyme and fermentation inhibitors. The SSF assay does not measure the extent of cellulose conversion to glucose because of the presence of soluble (non-cellwall) sugars (e.g., fructose and glucose) and the effect of inhibitors, and it is possible that the fraction of cellulose more readily converted to glucose following a low-severity pretreatment is not directly proportional to cellulose content across the whole population. This was observed in a study that included switchgrass samples at different maturity levels. The postfrost samples were richer in cellulose content than the samples at anthesis, but both gave the same glucose yields [17].

\section{Analysis of Cell Wall Components}

Of the two methods that were used to determine compositional traits of Bermuda grass, the Uppsala method is more accurate in terms of identifying cell wall components (i.e., lignin, hemicelluloses, and cellulose). However, the detergent method remains the mainstay for determining forage quality, and therefore, numerous past studies are available. Neutral detergent fiber is often used as an estimate of total cell wall fiber which includes hemicellulose, cellulose, and lignin. However, recently, Casler and Hatfield [16] found that bromegrass lines that were selected for divergent NDF were in fact not different for actual cell wall concentration or composition. There was a significant positive correlation $(r=0.85)$ in this study between NDF and cell wall (data not shown). 
Table 6 Best forward and backward stepwise multipleregression models for IVDMD, for models with all variables, ash and DFA, or ash and CWA

\begin{tabular}{|c|c|c|c|c|}
\hline \multirow{3}{*}{$\begin{array}{l}\text { Table } 6 \text { Best forward and back- } \\
\text { Nard stepwise multiple- } \\
\text { egression models for IVDMD, } \\
\text { or models with all variables, } \\
\text { sh and DFA, or ash and CWA }\end{array}$} & Variable & Parameter est. & $F$ value & $p>F^{\mathrm{a}}$ \\
\hline & \multicolumn{4}{|c|}{ IVDMD - all parameters (full model $R^{2}=0.94$ ) } \\
\hline & \multicolumn{4}{|c|}{ Forward selection $\left(R^{2}=0.94\right)$} \\
\hline & NDF (DFA) & -0.65 & 27.79 & $<0.001$ \\
\hline & Hemicellulose (DFA) & -21.62 & 12.40 & 0.004 \\
\hline & Cellulose (DFA) & -35.36 & 12.12 & 0.004 \\
\hline & ADL (DFA) & -19.09 & 11.86 & 0.004 \\
\hline & Total nitrogen & 0.40 & 23.15 & $<0.001$ \\
\hline & Pentose sugars (CWA) & -0.14 & 3.62 & 0.080 \\
\hline & \multicolumn{4}{|l|}{ Backward selection $\left(R^{2}=0.93\right)$} \\
\hline & NDF (DFA) & -0.61 & 43.87 & $<0.001$ \\
\hline & Hemicellulose (DFA) & -24.84 & 18.57 & $<0.001$ \\
\hline & Cellulose (DFA) & -40.52 & 18.04 & $<0.001$ \\
\hline & ADL (DFA) & -21.96 & 17.78 & $<0.001$ \\
\hline & Total carbon & 0.17 & 3.36 & 0.087 \\
\hline & Total nitrogen & 0.35 & 26.63 & $<0.001$ \\
\hline & Glucose (CWA) & 0.24 & 4.41 & 0.053 \\
\hline & \% Ester-linked phenolics (CWA) & 0.18 & 6.38 & 0.023 \\
\hline & $\%$ Ether-linked phenolics (CWA) & 0.17 & 4.05 & 0.062 \\
\hline & \multicolumn{4}{|c|}{ IVDMD (DFA components + ash; full model $\left.R^{2}=0.72\right)$} \\
\hline & \multicolumn{4}{|l|}{ Forward selection $\left(R^{2}=0.69\right)$} \\
\hline & NDF & -0.77 & 51.08 & $<0.001$ \\
\hline & Hemicellulose & -0.40 & 20.77 & $<0.001$ \\
\hline & \multicolumn{4}{|l|}{ Backward selection $\left(R^{2}=0.71\right)$} \\
\hline & $\mathrm{NDF}$ & -0.72 & 80.16 & $<0.001$ \\
\hline & Hemicellulose & -14.85 & 4.51 & 0.039 \\
\hline & Cellulose & -23.85 & 4.25 & 0.045 \\
\hline & ADL & -12.97 & 4.24 & 0.045 \\
\hline & \multicolumn{4}{|c|}{ IVDMD $\left(C W A\right.$ components + ash; full model $\left.R^{2}=0.54\right)$} \\
\hline & \multicolumn{4}{|l|}{ Forward selection $\left(R^{2}=0.50\right)$} \\
\hline & Pentose sugars & -0.39 & 8.54 & 0.009 \\
\hline & $\%$ Ester-linked phenolics & 0.54 & 8.06 & 0.010 \\
\hline & \multicolumn{4}{|l|}{ Backward selection $\left(R^{2}=0.49\right)$} \\
\hline & $\%$ Klason lignin & -1.08 & 4.62 & 0.044 \\
\hline & Pentose sugars & -1.25 & 12.43 & 0.002 \\
\hline \multirow{2}{*}{$\begin{array}{l}\text { Only parameters with proba- } \\
\text { ility }(p<0.1) \text { included in the } \\
\text { nodel }\end{array}$} & Glucose & -1.70 & 6.45 & 0.019 \\
\hline & $\%$ Ester-linked phenolics & 0.49 & 5.28 & 0.032 \\
\hline
\end{tabular}

${ }^{a}$ Only parameters with probability $(p<0.1)$ included in the model
However, hemicellulose calculated from the difference between NDF and ADF and cellulose calculated from the difference between ADF and ADL are inaccurate due to hemicellulosic residues retained in the ADF fraction [31]. In this study, neither pentose sugars from CWA nor pentose release from SSF correlated with estimates of hemicellulose (primarily pentose sugars) from DFA. However, cellulose estimates from DFA did correlate with hexose sugars from CWA $(r=0.71)$. Also, it has been demonstrated that ADL is an underestimation of lignin content $[22,26]$. Klason lignin and ADL had a moderate positive correlation in this study $(r=0.56)$. DFA remains the predominant method for determination of fiber due to the extra cost and time required for CWA.

\section{Role of Cell Wall Components to Recalcitrance}

Both high fiber and high lignin content are often associated with reduction in conversion to ethanol or for IVDMD. Early studies of brown midrib corn and sorghum indicated negative correlations between digestibility and both lignin and fiber contents [19, 32]. However, studies have shown that high fiber is not always negatively correlated with IVDMD in Bermuda grass. Tifton 85 Bermuda grass, for 
example, has been shown to have very high digestibility and high NDF [29]. Tifton 85 and a plant accession (PI 291614) with high ethanol production in this study had NDF comparable to Coastal (Table 2). Although NDF was only moderately correlated with ethanol production (Fig. 1), variation in NDF accounted for a major portion of the $R^{2}$ of multiple regressions on both ethanol production and IVDMD in this study (Tables 4 and 6). Supporting this was the observation that a significant portion of the variation in the CWA model of IVDMD was explained by the total cell wall (Table 6). Alternatively, Klason lignin had low correlation coefficients to most measures of degradability (Table 3 ) and made only minor contributions to multiple regressions (Table 4) for ethanol production. ADL had a more significant contribution to the IVDMD full model (Table 6). The lignin concentration of Bermuda grass is lower than many of the bunch grasses such as switchgrass [17] and napier grass [9] and may not be a useful target for genetic improvement of degradability.

The reduced recalcitrance of Tifton 85 to digestion has been attributed to reduced levels of indigestible ferulate ester/ether cross linkages between arabinoxylan and lignin [29]. However, the ester-linked and ether-linked ferulate concentrations for Tifton 85 were among the highest (Table 2) of the 50 entries, and no trend was observed between the ferulates and ethanol production. Additionally, ferulates only contributed a small amount to the variation in both ethanol production and IVDMD (Tables 4 and 6). This is most likely due to multiple mechanisms involved in recalcitrance among Bermuda grass germplasm. Studies on digested nonlignified cell walls indicated that the highly digestible Coastcross 1 (CC 1) had identical structure in the recalcitrant mestome sheath cells to those in less-digestible Coastal Bermuda grass but had reduced levels of hydroxycinnamic acid ester linkages in the parenchyma bundle sheath cells [7]. Results from the current study indicated that entries CC 2 and CC 3 , which are very closely related to CC 1 , had low concentrations of both ester and ether-linked hydroxycinnamates (Table 2).

\section{Effects of Cell Wall Components on Ethanol Yields}

Although glucose levels were not significantly correlated with ethanol yields, glucose content was an important trait in multiple-regression models (Table 4). As glucose is the primary fermentation substrate for the yeast, high glucose levels are desirable for maximum ethanol yield. There was also no direct relationship between glucose concentration and ethanol yield in stover among various maize varieties with diverse stover composition and digestibility [28]. Their estimate of convertibility (percentage of measured glucose converted to ethanol) was negatively correlated with ADL and Klason lignin. However, when convertibility and glucose concentrations were combined, regression coefficients were improved. The authors' conclusions were that improvements in ethanol yield occur primarily from improved cell wall degradation and conversion and then greater structural carbohydrate content once convertibility is improved and controlled.

There are indications from our data that perhaps the hemicellulose portion of the cell wall plays a greater role in reducing ethanol production. Pentose sugar concentration was negatively correlated with ethanol production (Table 3) and was the predominant factor in multipleregression models for ethanol production with CWA (Table 4). Hemicellulose can inhibit cellulose conversion into glucose by cellulase via two mechanisms. First, hemicelluloses block access to the cellulose fibers. As such, good extraction efficiency of hemicellulose from the cell wall matrix by the pretreatment is beneficial for cellulose conversion [42]. Secondarily, solubilized carbohydrates originating from xylan are inhibitory to cellulases [27]. Xylose is also inhibitory to $\beta$-glucosidase but less so than are xylan oligomers. Fermentation inhibitors include 5-hydroxymethylfurfural (from fructose and glucose degradation), furfural (from arabinose and xylose degradation), and organic acids released from hemicellulose side chains. Therefore, the negative correlation observed between hemicellulose components and ethanol yield is not unreasonable. The average percentage of the total pentose sugars released by dilute acid pretreatment and SSF was $75 \%$ and ranged between $65 \%$ and $84 \%$ (data not shown). However, there was no significant correlation between the percent pentose sugars released and ethanol yield or between pentose release and lignin concentration. This would imply that lignin does not impact the efficiency of hemicellulose hydrolysis by the acid pretreatment. Nitrogen content of the forage did not affect ethanol production from SSF. This is not surprising as SSF fermentations were conducted using a standard basal medium, containing yeast extract $(10 \mathrm{~g} / \mathrm{l})$ and peptone $(20 \mathrm{~g} / \mathrm{l})$, which are very rich in usable nitrogen. Furthermore, $S$. cerevisiae is not proteolytic and unable to hydrolyze protein into useable free amino nitrogen [24]. Also, nitrogen content had no effect on in vitro gas production from NNG24 or NNG96 (data not shown). By contrast, nitrogen content of the forage had a major effect on variability of IVDMD. These data are consistent with reports that increased nitrogen uptake by Bermuda grass has also increased IVDMD [11]. The IVDMD procedure used in this study was adapted from Tilley and Terry [36] and included only $0.5 \mathrm{~g} / \mathrm{l}$ urea as nitrogen source, while the NNG method [40] used $\mathrm{NH}_{4} \mathrm{HCO}_{3}(0.8 \mathrm{~g} / \mathrm{l})$ and trypticase $(2 \mathrm{~g} / \mathrm{l})$. Cows from which ruminal fluid was 
collected for NNG were fed higher protein TMR diets, while cows sampled for IVDMD analyses were fed grass continuously. Under the latter condition, it is possible that the microflora responded positively to the differential amounts of $\mathrm{N}$ in the Bermuda grass forage.

\section{Conclusions}

Our hypothesis prior to this study was that there would be a strong correlation between ethanol production and ruminal digestibility. There was a positive relationship, but the correlation was weak. However, when the Bermuda grass accessions were tested with the in vitro ruminal gas measurement system (which determines NNG production), the relationship between ethanol production and in vitro gas production after $24 \mathrm{~h}$ was very strong. The results herein support the notion that both the ruminal microbes that contribute to NNG24 and the yeast (Saccharomyces cerevisiae D5A) that produce ethanol in the SSF assay easily converted hexose sugars initially. Conversion of the biomass to ethanol was independent of hexose concentration (as measured by CWA), which was not unexpected because a low-severity pretreatment had been chosen to magnify structural as opposed to compositional differences among the samples. These results are consistent with results from the corn stover experiment [28]. Alternatively, increased xylan content had a substantial negative effect on ethanol production. As Saccharomyces does not ferment pentose sugars, the effect would have to be indirect, possibly due to xylan (retained through the pretreatment) that hinders access to the cellulose and/or to hydrolyzed hemicellulose products that directly inhibited the cellulases. As the NNG system was allowed to progress to $96 \mathrm{~h}$, some of the xylans were digested and resulted in much higher correlations with the IVDMD procedure. When screening large numbers of samples, the in vitro gas production procedure (which is conducted under nonaseptic conditions) measured after $24 \mathrm{~h}$ would be recommended for the purpose of estimating ethanol production from hexoses and, to a lesser extent, for overall theoretical ethanol yields. Ethanol and pentose releases were influenced by many of the cell wall components but were best explained by the total cell wall or NDF present in the dry matter. This study as well as the recent study on corn stover [28] indicates that cell wall components associated with NDF have a major effect on the ability to convert biomass to ethanol via enzymatic hydrolysis and fermentation.

Acknowledgements The authors would like to acknowledge Ms. Patricia O'Bryan, Ted Jeo, Freddie Cheek, Jacolyn Merriman, Christine Odt, and Kim Darling for their technical help.

\section{References}

1. Aden A (2007) Biomass and biofuels: technology and economic overview. NREL/PR-510-41793.

2. Ahmed AER, Labavitch JM (1977) A simplified method for accurate determination of cell wall uronide content. J Food Biochem 1:361-365

3. Akin DE (1989) Histological and physical factors affecting digestibility of forages. Agron J 81:17-25

4. Akin DE, Chesson A (1989) Lignification as the major factor limiting forage feeding value especially in warm conditions. Proc Inst Grassland Congr 16:1753-1760

5. Anderson WF (2005) Development of a forage Bermuda grass (Cynodon sp.) core collection. Grassland Sci 51:305-308

6. Anderson WF (2006) Digestibility and fiber of a forage Bermuda grass core collection. In: Proceedings ASA-CSSA-SSSA International Meetings, Indianapolis, IN, November 12-16. http://a-c-s. confex.com/crops/2006am/techprogram/P21742.HTM

7. Anderson WF, Akin DE (2008) Structural and chemical properties of grass lignocelluloses related to conversion for biofuels. J Ind Microbiol Biotechnol 35:355-366

8. Anderson WF, Casler MD, Baldwin BS (2008a) Improvement of perennial forage species as feedstock for bio-energy. In: Vermerris W (ed) Genetic improvement of bioenergy crops. Springer, New York, pp 309-346

9. Anderson WF, Dien BS, Brandon SK, Peterson JD (2008) Assessment of Bermuda grass and bunch grasses as feedstock for conversion to ethanol. Appl Biochem Biotechnol 14:13-21

10. Anderson WF, Maas A, Ozias-Akins P (2009) Genetic variability of a forage Bermuda grass core collection. Crop Sci 49:13471358

11. Anderson WF, Parker M (2007) Fertilizer effects on Bermuda grass quality. In: Proceeding of the American Forage and Grassland Council Meeting, State College, PA June 24-27

12. Anderson WF, Peterson JD, Akin DE, Morrison WH III (2005) Enzyme pretreatment of grass lignocellulose for potential highvalue co-products and an improved fermentable substrate. Appl Biochem Biotechnol 121-124:303-310

13. Bremner JM (1996) Nitrogen - total. In: Sparks DL et al (eds) Methods of soil analysis. Part 3. Chemical methods. SSSA book series 5. SSSA and ASA, Madison, pp 1085-1121

14. Burton GW (1972) Registration of 'Coastcross-1' Bermuda grass. Crop Sci 12:125

15. Burton GW, Gates RN, Hill GM (1993) Registration of 'Tifton 85' Bermuda grass. Crop Sci 33:644-645

16. Casler MD, Hatfield RD (2006) Cell wall composition of smooth bromegrass plants selected for divergent fiber concentration. J Agric Food Chem 54:8206-8211

17. Dien BS, Jung HG, Vogel KP, Casler MD, Lamb JFS, Iten L et al (2006) Chemical composition and response to dilute-acid pretreatment and enzymatic saccharification of alfalfa, reed canary grass, and switchgrass. Biomass Bioenergy 30:880-891

18. Gelman A (2007) Scaling regression inputs by dividing by two standard deviations. Department of Statistics and Department of Political Science, Columbia University, New York, gelman@stat. columbia.edu, www.stat.columbia.edu/_gelman

19. Hanna WW, Monson WG, Gaines TP (1981) IVDMD, total sugars, and lignin measurements on normal and brown mibrib (bmr) sorghums at various stages of development. Agron J 73: 1050-1052

20. Hartley RD (1972) p-Coumaric and ferulic acid components of cell walls of ryegrass and their relationships with lignin and digestibility. J Sci Food Agric 23:1347-1354

21. Hartley RD, Ford CW (1989) Phenolic constituents of plant cell walls and wall biodegradability. In: Lewis NG, Paice MG (eds) 
Plant cell wall polymers: biogenesis and biodegradation. American Chemical Society, Washington, DC, pp 137-145

22. Hatfield RD, Jung HG, Ralph J, Buxton PJ, Weimer DR (1994) A comparison of the insoluble residues produced by the Klason lignin and acid detergent procedures. J Sci Food Agric 65:51-58

23. Iiyama K, Lam TBT, Stone BA (1990) Phenolic acid bridges between polysaccharides and lignin in wheat internodes. Phytochemistry 29:733-737

24. Ingledew WM (1999) Chapter 5: alcohol production by Saccharomyces cerevisiae: a yeast primer. In: Jaques KA, Lyons TP, Kelsall DR (eds) The alcohol textbook, 3rd edn. Nottingham Press, Nottingham, pp 49-88

25. Jung HG, Shalita-Jones SC (1990) Variation in the extractability of esterified $p$-coumaric and ferulic acids from forage cell walls. J Agric Food Chem 38:397-402

26. Jung HG, Varel VH, Weimer PJ, Ralph J (1999) Accuracy of Klason lignin and acid detergent lignin methods as assesses by bomb calorimetry. J Agric Food Chem 47:2005-2008

27. Kumar R, Wyman CE (2009) Effect of enzyme supplementation at moderate cellulase loadings on initial glucose and xylose release from corn stover solids pretreated by leading technologies. Biotechnol Bioeng 102:457-467

28. Lorenz AJ, Anex RP, Isci A, Coors JG, de Leon N, Weimer PJ (2009) Forage quality and composition measurements as predictors of ethanol yield from maize (Zea mays L.) stover. Biotechnol Biofuel 2:5

29. Mandebvu P, West JW, Hill GM, Gates RN, Hatfeld RD, Mullinix BG et al (1999) Comparison of Tifton 85 and Coastal Bermuda grasses for yield, nutrient traits, intake, and digestion by growing beef steers. J Anim Sci 77:1572-1586

30. Marten GC, Barnes RF (1980) Prediction of energy digestibility of forages with in vitro rumen fermentation and fungal enzyme systems. In: Pigden WJ, Blach CC, Graham M (eds) Proc. Int. Standardization of Analytical Methodology for Feeds, Ottawa, Canada. 12-14 Mar. 1979. Ind. Development Ctr. 134e, Ottawa, Canada, pp 67-71

31. Morrison IM (1980) Hemicellulosic contamination of acid detergent residues and their replacement by cellulosic residues in cell wall analysis. J Sci Food Agric 31:639-645
32. Muller LD, Barnes RF, Bauman LF, Colenbrander VF (1971) Variation in lignin and structural components of brown midrib mutants of maize. Crop Sci 11:413-415

33. Perlack RD, Wright LL, Turnhollow AF, Graham RL, Stokes B, Erbach DC (2005) Biomass as feedstock for a bioenergy and bioproducts industry: the technical feasibility of a billion-ton annual supply. DOE/GO-102005-2135, Oak Ridge National Laboratory Report US Dept. of Energy, Oak Ridge, TN

34. Ralph J, Hatfield RD, Grabber JH, Jung HG, Quideau S, Helm RF (1998) Cell wall cross-linking in grasses by ferulates and diferulates. In: Lewis NG, Sarkanen S (eds) Lignin and lignan biosynthesis. ACS, Washington, DC, pp 209-236

35. Theander O, Aman P, Westerlund E, Andersson R, Pettersson D (1995) Total dietary fiber determined as neutral sugar residues, uronic acid residues, and Klason lignin (The Uppsala Method): collaborative study. J AOAC Int 78:1030-1044

36. Tilley JM, Terry RA (1963) A two-stage technique for the in vitro digestion of forage crops. J Brit Grassl Soc 18:104-11

37. Van Soest PJ, Robertson JB, Lewis BA (1991) Methods for dietary fiber, neutral detergent fiber, and nonstarch polysaccharides in relation to animal nutrition. J Dairy Sci 74:3583-3597

38. Vogel KP, Pederson JF, Masterson SD, Toy JJ (1999) Evaluation of a filter bag system for NDF, ADF, and IVDMD forage analysis. Crop Sci 39:276-279

39. Watson ME, Issac RA (1990) Analytical instruments for soil and plant analysis. In: Westerman RL (ed) Soil testing and plant analysis. SSSA book series 3, 3rd edn. Madison, SSSA, pp 691704

40. Weimer PJ, Dien BS, Springer TL, Vogel KP (2005) In vitro gas production as a surrogate measurement of the fermentability of cellulosic biomass to ethanol. Appl Microbiol Biotechnol 67:5258

41. Weimer PJ, Springer TL (2007) Fermentability of eastern gama grass, big bluestem and sand bluestem grown across a wide variety of environments. Bioresource Tech 98:1615-1621

42. Yang B, Wyman CE (2004) Effect of xylan and lignin removal by batch and flow through pretreatment on the enzymatic digestibility of corn stover cellulose. Biotechnol Bioeng 86:88-95 